\title{
Implementation of Audio-Visual Learning Media in Elementary School
}

\author{
Azmi Al Bahij ${ }^{1}$, Khaerunisa ${ }^{1}$, Munifah Bahfen ${ }^{1}$, Ari Suryawan² ${ }^{2}$ \\ ${ }^{1}$ Faculty of Education, Muhammadiyah University of Jakarta, Indonesia \\ ${ }^{2}$ Department of Elementary School Teacher Education, Universitas Muhammadiyah Magelang, Magelang, Indonesia \\ *Corresponding author. Email: ari.surya_88@ummgl.ac.id
}

\begin{abstract}
This study aims to describe the use of audio-visual learning media in the teaching and learning process in the low class at Elementary School students related to the use of audio-visual media in the classroom, the responses and results of the varied and unique learning processes. This approach uses a qualitative approach. This research was conducted at Borobudur State Elementary School 1. Data collection techniques through observation, interviews, and documentation studies. The data analysis technique used is qualitative descriptive analysis and steps. 1) Data reduction, data display, and conclusion making. 2) The results of this study indicate: first, the use of audio-visual media, namely: (1) the attractiveness of students during the learning process in class takes place 3) students' understanding of the material delivered during the learning process. (3) and the efficiency of the time required by the teacher to explain more planned. Student responses to audiovisual utilization with the Good category were $78 \%$. Learning media is one component of learning that has an important role in the learning process. The use of media should be part of the attention of the teacher as a facilitator in every learning activity.
\end{abstract}

Keywords: audio-visual, learning media, elementary

\section{INTRODUCTION}

Learning media are all things that can convey or distribute messages from a source in a planned manner so that a conducive learning environment occurs where the recipient can carry out the learning process efficiently and Effectively [1]. The utilization of Learning Media certainly develops the mindset of teachers and students. The teacher is creative in its use, and the time efficiency required by the teacher in explaining is more planned. And students more quickly understand the material taught by the teacher. Learning media is one component of learning that has an important role in the learning process. The use of media should be part of the attention of the teacher as a facilitator in every learning activity.

\section{METHOD}

This research is quantitative research with experimental research type. This study aims to determine the effect of the use of audiovisual learning for elementary school students. Experimental research is always carried out with a view to seeing the effects of treatment [2].The design used in this study is the pretest-posttest control group design. The population in this study were all elementary school students in Borobudur District in the second semester. The population sampled in this study was class 2 as an experimental class with a total of 32 students and class 2 as a control class with a total of 30 students. Data collection methods used were tests and questionnaires. Data analysis included the normality test, two variance similarity test, and two mean difference tests.

\section{RESULT AND DISCUSSION}

This research was divided into an experimental group and a control group. One group was given certain special treatment, and another group was not given treatment. The experimental group was the group that received treatment, namely by using the Audiovisual Learning Model during learning. While the control group uses conventional learning models (lectures). This preliminary analysis is a questionnaire data analysis, and a pre-test is used to determine whether the sample used in this study has the same or different abilities before treatment with different methods. The experimental group used the learning process using Audio Visual, while the control class used conventional learning methods (lectures). This initial stage of analysis consists of two kinds, namely analysis of learning motivation and analysis of learning outcomes

Normality Test is used to determine whether the data analyzed is normally distributed or not. Based on the analysis of motivation and learning outcomes obtained $\chi^{2}$ arithmetic $<$ t2table with $\mathrm{DK}=6$ and $\alpha=5 \%$, it can be obtained that Ho is accepted, which means the data is normally distributed.

The homogeneity test (similarity of two variances) is used to determine the homogeneity of two samples. Based on the results of the analysis of motivation and learning outcomes, the calculated $\mathrm{F}$ value is smaller than the $\mathrm{F}$ table. Then it can be concluded that Ho was accepted. This means that the 
data from the experimental class and the control class have the same variance (homogeneous).

The average difference test is a test to find out whether there is a significant difference between the experimental class and the control class. Based on the results of the analysis of motivation and learning outcomes, it was concluded that Ho was accepted, which means there were no differences in motivation and learning outcomes between the experimental class and the control class. So, the sample starts from the same situation. The results of this final stage of the analysis are the results of testing the latest data obtained from the test of learning outcomes and questionnaires given to the experimental class and the control class after being given different learning treatments. A normality test is used to determine whether the data analyzed is normally distributed or not. Based on the analysis of motivation and learning outcomes obtained $\chi^{2}$ calculated $<\chi 2$ table with $\mathrm{DK}=6$ and $\alpha=5 \%$, it can be obtained that Ho is accepted, which means the data is normally distributed Based on the results of the analysis of research data, it is known that the average increase in student learning outcomes in the experimental group is higher than the mathematics learning outcomes in the control group. The difference between the pretest and posttest results of the experimental and control groups is as follows:

Table 1 Experimental Group and Control Group Value Data Results

\begin{tabular}{|lcccc|}
\hline \multicolumn{1}{|c}{ Group } & N & $\begin{array}{c}\text { Lowest } \\
\text { Score }\end{array}$ & $\begin{array}{c}\text { Highest } \\
\text { Score }\end{array}$ & Average \\
\hline Pretest Experiment & 24 & 58 & 90 & 74,67 \\
\hline Pretest Control & 24 & 54 & 98 & 75,16 \\
\hline Posttest Experiment & 24 & 70 & 100 & 85,25 \\
\hline Posttest Control & 24 & 64 & 98 & 78,91 \\
\hline
\end{tabular}

Table 1 shows that the acquisition of pretest scores in the experimental group with the lowest value was 58, the highest value was 90, and the average value was 74.67. Posttest value of the experimental group with the lowest value of 70, the highest value of 100, and an average value of 85.25. While the acquisition of the pretest value in the control group with the lowest value of 54, the highest value of 98 , and an average value of 75.16 . The posttest score of the control group with the lowest value is 64 , the highest is 98 , and the average value is 78.91. Based on the data mentioned above, the average increase in learning outcomes in the experimental class is higher than the control class. The homogeneity test conducted in this study is to use the Levene Statistical test with the help of SPSS 23.00 for windows. Homogeneity test results are presented in the following table:

Table 2 Homogeneity Test Results

\begin{tabular}{|lllll|}
\hline Group & $\begin{array}{l}\text { Levene } \\
\text { Statistic }\end{array}$ & $\begin{array}{l}\text { Sig. Based } \\
\text { on Mean }\end{array}$ & $\begin{array}{l}\text { Inform } \\
\text { ation }\end{array}$ & Result \\
\hline $\begin{array}{l}\text { Pretest } \\
\begin{array}{l}\text { Experiment } \\
\text { and Control }\end{array}\end{array}$ & 1,226 & 0,274 & $>0,05$ & Homogeny \\
\hline $\begin{array}{l}\text { Posttest } \\
\text { experiment } \\
\text { and control }\end{array}$ & 0,835 & 0,366 & $>0,05$ & homogeny \\
\hline
\end{tabular}

Table 2 shows that the value based on mean in the experimental and control pretest data with sig. 0.274>0.05, so it can be concluded that the pretest data is homogeneous. While the value based on mean in the experimental and control posttest data with sig values. $0.366>0.05$, so it can be concluded that the posttest data is homogeneous. Hypothesis testing is done by t-test (independent sample ttest) using SPSS 23.00 for windows. Provisions for decision making in the t-test analysis is if the value of sig. $>0.05$, then the average is equal, or Ho is accepted, whereas if the value of sig. $<0.05$, then the average is different, or Ho is rejected, and if tcount $>\mathrm{t}$ table, then Ho is rejected, and if $\mathrm{t}$ count $<\mathrm{t}$ table, then Ho is accepted.

Table 3 Hypothesis Test Results with Independent Sample t-test

\begin{tabular}{|lll|}
\hline Data Collected & Sig. (2-tailed) & Result \\
\hline $\begin{array}{l}\text { Learning outcomes of } \\
\text { the experimental and } \\
\text { control posttest groups }\end{array}$ & 0,018 & significant \\
\hline
\end{tabular}

Table 3 shows that the t-test data from the experimental and posttest group's learning outcomes with sig. (2-tailed) 0.018 $<0.05$. This means that $\mathrm{H}_{\mathrm{O}}$ is rejected or $\mathrm{H}_{\mathrm{a}}$ is accepted, so it can be concluded that Audio-Visual Media has a positive effect on improving student learning outcomes. The increase in learning outcomes is strengthened by the results of treatments that have been carried out. The results of the first treatment that students are able to understand the material provided by observing the video displayed, this is influenced by the psychological condition of students to see and listen more easily digested by their brains through visual video [3] .The results of the second treatment are that students are able to solve problems and everyday problems related to the material provided. The provision of contextual problems through videos relating to daily life has an impact on the level of student understanding and can help the memory structure of students [4]. The results of the third treatment are that students are able to understand the indicators and learning objectives delivered through messages from the video displayed, and students are able to solve problems related to daily life with a systematic and logical flow of thinking [5]. This is reinforced by the results of the evaluation at the end of each treatment with a value above the minimum completeness criteria.

The conventional learning used by researchers in the control group causes students to be less active and less focused on the material being studied. So the teaching and learning process in the control group can be said to be less effective. This shows that learning with conventional approaches makes learning less meaningful and makes students less active [6]. Audiovisual learning has a positive effect on the increase in learning outcomes, because the learning approach is based on things that are real to students, emphasizes mathematical process skills (the process of doing mathematics), discussing and collaborating, arguing with classmates so they can find out for themselves what is being learned, which ultimately uses mathematics to solve problems both individually and in groups.

Learning helps students in understanding the material being studied, and students can relate the subject matter to the real world in order to reduce students' abstracts in thinking or in 
[2] Suharsimi Arikunto, Prosedur Penelitian Suatu Pendekatan Praktik ( Edisi Revisi IV ). Jakarta: PT Rineka Cipta, 2006.

[3] A. P. Asmara, "Pengembangan Media Pembelajaran Berbasis Audio Visual Tentang Pembuatan Koloid," J. Ilm. Didakt., vol. 15, no. 2, p. 156, 2015.

[4] Sayidiman, "Penggunaan Media Audio Visual Dalam Merangsang Minat Mahasiswa Terhadap Mata Kuliah Seni Tari," J. Publ. Pendidik., vol. 2, no. 1, pp. 36-43, 2012.

[5] J. SIDI and M. MUKMINAN, "Penggunaan Media Audiovisual untuk Meningkatkan Hasil belajar IPS di SMP," SOCIA J. Ilmu-Ilmu Sos., vol. 13, no. 1, pp. 5372, 2016.

[6] N. Nita and E. Surya, "PENGARUH Pembelajaran Dengan Pendekatan Pendidikan Matematika Realistik ( Pmr ) Terhadap Hasil Belajar Matematika," no. December, 2017.

[7] N. S. Widyastuti and P. Pujiastuti, "Pengaruh Pendidikan Matematika Realistik Indonesia (Pmri) Terhadap Pemahaman Konsep Dan Berpikir Logis Siswa,” J. Prima Edukasia, vol. 2, no. 2, p. 183, 2014.

[8] S. Rasul, Q. Bukhsh, and S. Batool, "A study to analyze the effectiveness of audio visual aids in teaching learning process at uvniversity level," Procedia - Soc. Behav. Sci., vol. 28, pp. 78-81, 2011.
[1] D. Gerlach, V.S., \& Ely, Teaching \& Media: A Systematic Approach. Englewood Cliffs: Prentice-Hall Incorporated., 1980. 